\title{
Preferensi Masyarakat tentang Lingkungan Perumahan yang Ingin Ditinggali
}

\section{Andina Syafrina'; Angela Christysonia Tampubolon'1; Suhendri'; Nunik Hasriyanti²; Hanson E Kusuma ${ }^{1}$}

${ }_{1}^{1}$ Sekolah Arsitektur, Perencanaan dan Pengembangan Kebijakan, Institut Teknologi Bandung

2 Program Studi Arsitektur, Politeknik Negeri Pontianak

andina.syafrina@gmail.com

\begin{abstract}
ABSTRAK
Pembangunan perumahan perlu ditunjang oleh pedoman tertentu yang dikeluarkan oleh instansi berwenang untuk pencapaian kelayakan pembangunan. Partisipasi masyarakat sebagai pelaku utama dan pengguna turut mengambil bagian penting agar pembangunan perumahan menjadi tepat sasaran. Kekecewaan masyarakat seringkali disebabkan oleh hasil yang tidak sesuai keinginan ataupun tidak sesuai standar. Tujuan penelitian adalah untuk mengetahui preferensi masyarakat pada lingkungan perumahan yang ingin ditinggali, sehingga dapat membuka potensi baru dalam perencanaan maupun perancangan lingkungan perumahan yang sesuai dengan keinginan. Penelitian ini dilakukan secara kualitatif yang bersifat eksploratif menggunakan pendekatan grounded theory. Pengumpulan data dilakukan dengan kuesioner online yang bersifat terbuka (openended) dan dibagikan secara bebas (non-random sampling). Data yang terkumpul kemudian dianalisis secara kualitatif menggunakan metode analisis isi. Temuan menunjukkan terdapat lima aspek yang menjadi preferensi lingkungan perumahan (5 PLP) yaitu kenyamanan lingkungan, sarana lingkungan, prasarana lingkungan, lokasi dan aksesibilitas serta desain bangunan maupun lingkungan perumahan.
\end{abstract}

Kata kunci: Analisis isi, lingkungan perumahan, preferensi masyarakat

\section{ABSTRACT}

Housing development needs to be supported by particular guidelines issued by authorized institute for the achievement of development feasibility. Community participation as the main actors and users also took an important part for housing development to fit the target. Community disappointment is often caused by results that do not match the desires or not according to standards. The aim of this study was to find the preferences of the community related to the housing environment to be occupied, so it can open the new possibility in planning and designing the housing environment. This research uses exploratory qualitative and grounded theory method. Data collection is done through an open-ended online questionnaire and shared freely (non-random sampling). The collected data was analyzed qualitatively using the content analysis methods. The result showed that the five aspects that become the preference of residential environment (5 PRE) namely: environmental comfort, environmental facilities, environmental infrastructure, location and accessibility, building and residential environment design.

Keywords: Content analysis, residential environment, community preferences

\section{Pendahuluan}

Pembangunan yang berkaitan dengan tempat tinggal dan lingkungannya perlu mendapatkan prioritas, mengingat tempat tinggal merupakan salah satu kebutuhan dasar 
manusia selain sandang dan pangan. Tempat tinggal memiliki peran dinamis yang bukan hanya sebagai tempat bernaung dan berlindung melainkan berhubungan erat dengan manusia sebagai penghuni yang memiliki aturan, perilaku serta keinginan yang terus berkembang sesuai dengan konteks pada masanya (Santoso \& Riviwanto, 2011). Dengan demikian preferensi seseorang terhadap tempat tinggalnya pun tidak akan pernah berhenti pada aspek tertentu pada suatu saat saja.

Preferensi dalam bertempat tinggal adalah kecenderungan seseorang untuk berhuni atau tidak berhuni di suatu tempat (Budiharjo, 1994; Rahman dkk, 2015). Preferensi terhadap tempat tinggal akan selalu berkembang sesuai dengan dinamika perilaku (Zinas dkk, 2012) serta kondisi sosial dan ekonomi seseorang (Budiharjo, 1994). Kondisi tersebut dapat berdampak pada perubahan unsur lingkungan tempat tinggalnya seperti fasilitas, layanan, aksesibilitas hingga pola spasial perumahan (Towers, 2005). Preferensi merupakan salah satu studi keperilakuan dalam arsitektur yang memiliki manfaat dalam menjelaskan dan memprediksi perilaku manusia dalam kehidupan sehari-hari sehingga dapat dihasilkan karya-karya yang lebih baik (Handler dan Canter dalam Sueca 2001).

Dengan semakin meningkatnya pembangunan perumahan yang dilakukan oleh pemerintah maupun pengembang, maka semakin banyak pula pilihan bagi konsumen untuk memilih perumahan yang akan ditinggali. Preferensi terkait tempat tinggal menjadi hal yang penting untuk pemerintah maupun pengembang agar pembangunan perumahan menjadi tepat sasaran. Penelitian terdahulu menunjukkan bahwa preferensi terkait perumahan meliputi aksesibilitas dan lokasi perumahan, tipe dan desain bangunan, karakteristik fisik lingkungan, ketersediaan fasilitas dan pelayanan dan faktor harga (Anindyajati dkk, 2014; Nadiya, 2017; Tambunan, 2009). Faktor lainnya yang juga menjadi preferensi terkait perumahan yaitu faktor kenyamanan dan keamanan baik secara fisik maupun secara non fisik seperti lingkungan sosial yang stabil dan kedekatan dengan keluarga (Anindyajati dkk, 2014; Dokmeci dkk, 1996; Nadiya, 2017), legalitas dan kredibilitas pengembang yang juga dianggap penting guna menghindari permasalahan hukum di kemudian hari (Winanto dkk, 2016).

Berkaitan dengan hal tersebut, penelitian ini merupakan studi awal untuk mengetahui preferensi masyarakat terkait lingkungan perumahan yang ingin ditinggali. Penelitian ini diharapkan dapat mengeksplorasi kebutuhan di dalam perencanaan maupun perancangan lingkungan perumahan yang sesuai dengan keinginan masyarakat.

\section{Bahan dan Metode}

Penelitian ini dilakukan secara kualitatif dan bersifat eksploratif, menggunakan pendekatan grounded theory. Grounded theory adalah suatu metode penelitian kualitatif dimana peneliti menghasilkan penjelasan umum (teori) dari suatu fenomena, proses, tindakan atau interaksi yang dibentuk oleh responden (Budiasih, 2014; Creswell, 2007). Data yang terkumpul dianalisis, ditafsirkan, dan disusun dalam bentuk model hipotesis. Perolehan data berupa informasi mengenai aspek-aspek yang menjadi preferensi responden tentang lingkungan perumahan yang ingin ditinggali.

Pemilihan sampel dilakukan menggunakan metode non-random sampling dengan teknik accidental sampling. Accidental merupakan teknik penentuan sampel secara kebetulan (siapa yang kebetulan bertemu/ dijumpai) yang dianggap cocok dengan karakteristik pertanyaan yang telah ditentukan (Kumar, 2005). Langkah yang dilakukan dalam pengumpulan data yaitu melalui penyebaran kuesioner secara online. Kuesioner online bersifat terbuka (open-ended) yang mana dalam menjawab pertanyaan, responden diminta untuk berpendapat secara bebas dengan harapan jawaban yang akan didapatkan sesuai dengan yang dirasakan, dipikirkan, dan preferensi responden terkait lingkungan perumahan yang ingin ditinggali. 
Kuesioner online dibagikan secara bebas melalui media sosial tanpa ada batasan lokasi, umur, pekerjaan, pendidikan maupun jenis kelamin. Proses pengumpulan data dilakukan selama 4 hari dari tanggal 26 hingga 29 Agustus 2017 dengan jumlah responden yang terkumpul sebanyak 235 orang, dengan rincian 102 orang laki-laki dan 133 orang perempuan. Rentang usia berkisar kurang dari 20 tahun hingga lebih dari 50 tahun. Tingkat pendidikan mulai dari SMP hingga S2. Perkerjaan responden bervariasi, yaitu dosen, guru, ibu rumah tangga, pegawai swasta, pelajar/mahasiswa, PNS, dan wiraswasta. Berkenaan dengan penghasilan berkisar kurang dari 1 juta rupiah hingga lebih dari 5 juta rupiah. Asal daerah responden bervariasi yang terdiri dari Kota Pontianak dan Kabupaten Pontianak, Kabupaten Kapuas Hulu, Mempawah, Sintang, Singkawang, Balikpapan dan Samarinda, Kota Bandung dan Kabupaten Bandung, Jakarta, Tangerang, Surabaya, Malang, Kediri dan Madiun. Lingkungan tempat tinggal responden terdiri dari komplek perumahan landed (dibangun pengembang dan pemerintah), apartemen, kampung kota dan pedesaan.

Data yang telah didapat kemudian dianalisis dengan metode analisis isi yang dilakukan dalam tiga tahap yaitu open coding, axial coding, dan selective coding (Creswell, 2007). Tahap open coding, merupakan tahap melakukan identifikasi kata kunci dari jawaban responden. Tahap axial coding, merupakan tahap membuat kategori dengan kata yang lebih umum melalui pengelompokan kata kunci yang memiliki kedekatan makna ataupun sifat. Pada tahap ini pengkategorian dilakukan dengan diskusi kelompok agar pemilihan kata tidak bias. Frekuensi dari masing-masing kategori disajikan dalam bentuk diagram melalui analisis distribusi. Tahap selective coding merupakan tahap menyusun model hipotesis berdasarkan kategori-kategori yang didapatkan dari tahap axial coding.

\section{Hasil dan Diskusi}

Tahap awal pada analisis isi dilakukan open coding dari jawaban responden terkait kualitas lingkungan perumahan yang ingin ditinggali. Contoh open coding dari jawaban responden dapat dilihat pada kutipan berikut.

"Kawasan perumahan yang banyak pohon / tanaman hijau dan memiliki fasilitas di perumahan seperti lapangan olahraga atau taman kompleks." (Perempuan, Pegawai Swasta)

"Kawasan perumahan yang menyediakan lebih banyak fasilitas umum, yang bisa digunakan oleh warga setempat untuk berinteraksi lebih banyak satu sama lain. Seperti taman bermain, rumah baca, jogging track." (Perempuan, Wiraswasta)

Berdasarkan kutipan tersebut didapatkan beberapa kata kunci yakni "terdapat banyak vegetasi", "fasilitas olahraga dan taman", "ruang komunal". Temuan kata-kata kunci kemudian dikelompokkan menjadi sub-kategori dan kategori (axial coding). Berdasarkan hasil analisis terhadap data teks ditemukan 6 kategori terkait aspek-aspek lingkungan perumahan yang ingin ditinggali. Adapun pengelompokan kategori tersebut dibagi dalam dua aspek (Tabel 1), yaitu aspek fisik (kategori prasarana, sarana, aksesibilitas dan lokasi, desain) dan non fisik (kategori kenyamanan lingkungan, regulasi dan biaya). 
Tabel 1: Hasil Axial Coding Kualitas Lingkungan Perumahan yang Ingin Ditinggali

\begin{tabular}{|c|c|c|}
\hline Sub Kategori & $\mathrm{F}$ & Kategori \\
\hline Jaringan air bersih & 22 & \multirow{5}{*}{$\begin{array}{c}\text { Prasarana } \\
\text { (122) }\end{array}$} \\
\hline Jaringan listrik, internet dan telepon & 18 & \\
\hline Jaringan drainase & 32 & \\
\hline Jaringan jalan & 24 & \\
\hline Jaringan Sanitasi dan Persampahan & 16 & \\
\hline Sarana Pelayanan Umum dan Pemerintahan & 16 & \multirow{6}{*}{$\begin{array}{l}\text { Sarana } \\
\text { (231) }\end{array}$} \\
\hline Sarana Kesehatan & 17 & \\
\hline Sarana Pendidikan & 21 & \\
\hline Sarana Perbelanjaan/ Perniagaan & 19 & \\
\hline Sarana Pertamanan dan RTH & 137 & \\
\hline Sarana Peribadatan & 21 & \\
\hline Kemudahan aksesibilitas & 21 & \multirow{8}{*}{$\begin{array}{l}\text { Lokasi dan Aksesibilitas } \\
\text { (108) }\end{array}$} \\
\hline Jalur Pedestrian & 16 & \\
\hline Transportasi publik & 15 & \\
\hline Keterbukaan fungsi lahan & 4 & \\
\hline Strategis & 39 & \\
\hline Jauh dari TPA & 1 & \\
\hline Perkotaan & 9 & \\
\hline Pedesaan & 3 & \\
\hline Jenis Hunian & 14 & \multirow{3}{*}{$\begin{array}{l}\text { Desain } \\
\text { (74) }\end{array}$} \\
\hline Gaya Bangunan dan Kawasan & 32 & \\
\hline Tata Lingkungan dan Bangunan & 28 & \\
\hline Kesehatan Lingkungan & 58 & \multirow{4}{*}{$\begin{array}{c}\text { Kenyamanan Lingkungan } \\
\text { (288) }\end{array}$} \\
\hline Kenyamanan Lingkungan & 35 & \\
\hline Ketenangan Lingkungan & 127 & \\
\hline Hubungan Sosial & 68 & \\
\hline Manajemen Tata Kelola Perumahan & 1 & \multirow{2}{*}{$\begin{array}{c}\text { Biaya dan Regulasi } \\
\text { (2) }\end{array}$} \\
\hline Keterjangkauan Harga & 1 & \\
\hline
\end{tabular}

Perolehan kategori memiliki frekuensi yang dianalisis menggunakan analisis distribusi. Hasil analisis distribusi menunjukkan bahwa aspek-aspek lingkungan perumahan yang ingin ditinggali cenderung dipengaruhi oleh faktor kenyamanan lingkungan, sarana, prasarana, lokasi dan aksesibilitas, desain serta faktor biaya dan regulasi. Kategori faktor yang paling dominan muncul yaitu kenyamanan lingkungan sebesar 288 (54,96\%) disusul dengan sarana sebesar $231(44,08 \%)$. Faktor desain menjadi jawaban yang paling kecil yaitu sebesar $17(3,24 \%)$ dan disusul dengan faktor biaya dan regulasi sebesar $2(0,38 \%)$. Hasil analisis distribusi kategori aspek lingkungan perumahan dapat dilihat pada Gambar 1.

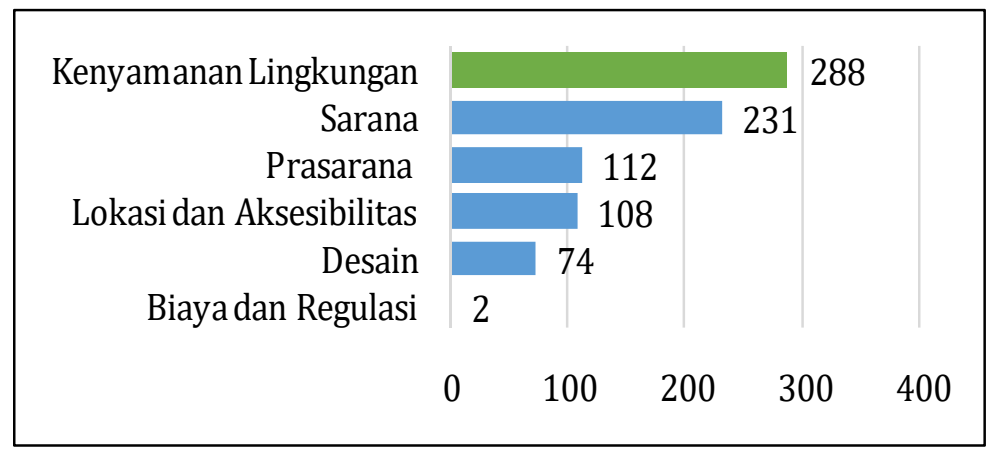

Gambar 1. Analisis Distribusi Frekuensi Kategori Faktor-faktor Lingkungan Perumahan 


\subsection{Analisis Kategori Faktor Kenyamanan Lingkungan}

Kenyamanan lingkungan menjadi faktor dominan dalam preferensi terhadap lingkungan perumahan yang ingin ditinggali. Pada faktor kenyamanan lingkungan perumahan bukan hanya sekedar untuk digunakan tetapi juga dapat memberikan suasana yang nyaman baik pada diri penghuni maupun pada lingkungan sekitarnya. Faktor ini merupakan ranah yang luas dan dapat dipengaruhi oleh berbagai faktor, antara lain kenyamanan termal, kenyamanan audio, kenyamanan visual, keamanan serta kesehatan pada lingkungan perumahan maupun bangunan rumah tinggal (M.Sastra \& Marlina, 2006), seperti yang ada pada beberapa komentar responden dibawah ini.

"Tenang, aman, dan nyaman. Cukup strategis namun jauh dari keramaian kendaraan (tidak tepi jalan raya) serta memungkinkan untuk bersantai/berjalan di sekitar rumah tanpa perlu khawatir (Mahasiswa)"

"Tempat yang tenang, adem, udara segar, dan aman (Mahasiswa)"

"Yang antar tetangganya dekat tapi tidak sampai menganggu, kawasan yang aman dan tidak terlalu berisik (Mahasiswa)"

"Kawasan perumahan penduduk yang ramah dengan tetangga terjalin silaturahminya (Dosen)"

Terdapat tiga faktor dominan yang mempengaruhi kenyamanan lingkungan (Gambar 2) yaitu ketenangan lingkungan sebesar 127 (44,09\%), hubungan sosial sebesar 68 (23,61\%), kesehatan lingkungan sebesar 58 (20,13\%) dari jumlah aspek kenyamanan lingkungan.

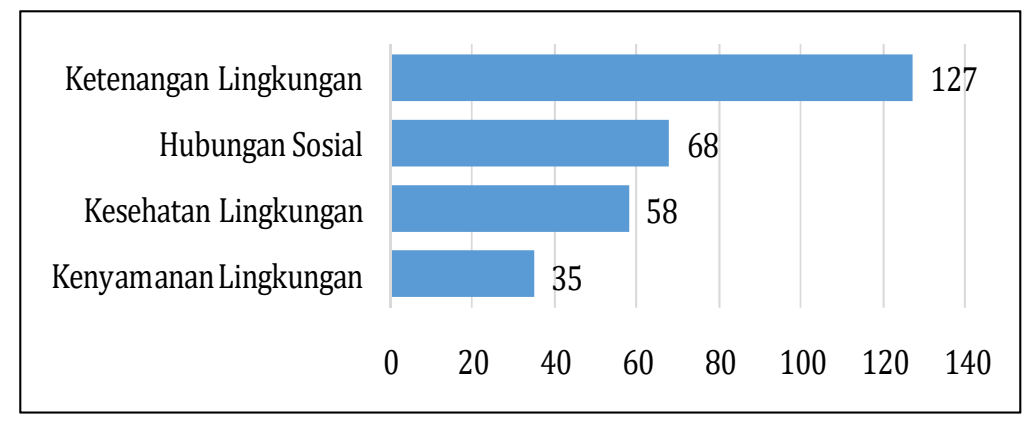

Gambar 2. Analisis Distribusi Frekuensi Kategori Kenyamanan Lingkungan

Ketenangan lingkungan dipengaruhi oleh kondisi lingkungan yang aman, tingkat kebisingan rendah dan privasi. Berdasarkan deskripsi data teks yang diuraikan responden, yang dimaksud dengan lingkungan perumahan yang aman adalah aman dari tindak kejahatan sehingga selain merasa aman di dalam rumah, penghuni juga dapat bersantai ataupun berjalan di lingkungan perumahan tanpa perlu merasa khawatir. Faktor yang mempengaruhi rasa aman misalnya tidak terdapat aliran sesat pada perumahan yang dapat mengganggu ketenangan masyarakat. Faktor keamanan ini juga harus didukung dengan ketersediaan fasilitas keamanan berupa pos penjagaan, serta sistem siskamling. Hal tersebut sejalan dengan Maslow (1994) yang menyatakan salah satu kebutuhan dasar manusia yaitu 
kebutuhan terhadap keamanan (safety needs) pada tingkatan ini hunian merupakan sarana perlindungan untuk keselamatan penghuni baik secara psikis maupun fisik.

Faktor lain yang mempengaruhi ketenangan lingkungan yaitu terkait dengan tingkat kebisingan yang rendah pada lingkungan perumahan. Dari hasil analisis, ditemukan bahwa tingkat kebisingan dapat disebabkan pengendara kendaraan bermotor yang ugal-ugalan saat melintas di lingkungan perumahan. Selain itu tingkat kebisingan pada lingkungan sangat mempengaruhi kenyamanan audio pada rumah tinggal. Pada kondisi ini, perancangan rumah memerlukan solusi untuk mereduksi kebisingan yang berasal dari luar bangunan, seperti memasang material peredam bunyi pada dinding atau melalui penataan lansekap yang dapat mereduksi bunyi pada rumah. Begitu pula sebaliknya perlu diperhatikan kebisingan yang ditimbulkan dari rumah seperti studio musik dan lainnya, yang dapat mengganggu ketenangan lingkungan, sehingga dapat dipertimbangkan desain bangunan yang dapat meredam bunyi (M.Sastra \& Marlina, 2006).

Ketenangan lingkungan juga dipengaruhi oleh adanya kebutuhan akan privasi. Laurens (2004) menyatakan privasi merupakan kecenderungan individu ataupun kelompok untuk mengendalikan interaksi dengan orang lain, baik secara visual, audio maupun olfaktori. Setiap orang bisa mempunyai keragaman akan harapan tinggi rendahnya privasi yang bergantung pada pola perilaku, latar belakang budaya, kepribadian dan aspirasinya. Berdasarkan hal tersebut pada penelitian ini dapat diinterpretasikan bahwa di dalam perancangan baik lingkungan perumahan maupun huniannya perlu dapat memfasilitasi privasi misalnya melalui hierarki ruang sehingga dapat memaksimalkan kemampuan individu ataupun kelompok dalam mengatur interaksi dengan sesamanya.

Hubungan sosial merupakan salah satu faktor yang mempengaruhi faktor kenyamanan lingkungan. Berdasarkan hasil analisis isi yang termasuk dalam faktor hubungan sosial yaitu interaksi sosial yang baik antar tetangga, rasa kekeluargaan, suasana lingkungan yang damai serta lingkungan yang religius.

Rasa kekeluargaan dan interaksi sosial yang baik dapat memberikan rasa tenang, aman, damai dan kebetahan bagi penghuni lingkungan perumahan. Selain itu lingkungan yang religius juga menjadi salah satu pertimbangan dalam faktor hubungan sosial, menurut Aini (2015) alasan seseorang memilih lingkungan yang religius yaitu lingkungan yang kondusif untuk ibadah, serta dapat memberikan kenyamanan \& keamanan secara fisik maupun batin.

Manusia sebagai makhluk sosial memiliki kebutuhan akan hubungan sosial yang selalu terkait dengan interaksi antara yang satu dengan yang lainnya (Maslow, 1994). Hubungan sosial tersebut menjadi penting karena didasari oleh kebutuhan manusia yang dapat dipenuhi apabila mendapat bantuan dari manusia yang lain (Abdulkadir dalam Tamboeo, 2016). Perumahan merupakan perwujudan dari hubungan antara bangunan ataupun lingkungan hunian dan manusia sebagai penghuni. Dengan adanya hubungan sosial suatu masyarakat dapat terbentuk dan mengisi lingkungan perumahan.

Faktor lain yang mempengaruhi kenyamanan lingkungan yaitu kesehatan lingkungan. Faktor ini sangat berperan bagi keberlanjutan proses penghunian dalam suatu lingkungan perumahan maupun bangunan yang mana dapat dicapai dengan cara menghijaukan kembali lingkungan binaan, seperti tersedianya taman yang sekaligus menyediakan ruang bermain outdoor, penanaman pohon ataupun vegetasi (Tower, 2005). Dari analisis isi terdapat beberapa hal yang berpengaruh terhadap kesehatan lingkungan yaitu kebersihan, kesehatan dan kondisi udara yang baik, udara segar dan bebas polusi.

Jika dikaitkan dengan teori dan data teks responden sirkulasi udara yang baik, termasuk dalam kenyamanan termal. Sirkulasi udara yang baik merupakan tindakan adaptif penghuni untuk mencapai kenyamanan termal yang diinginkan (Santoso, 2012). Adaptasi masyarakat terhadap kenyamanan termal berbeda-beda yang dapat dipengaruhi oleh iklim 
maupun suhu udara di tiap daerah bahkan lingkungan tempat tinggal. Rancangan hunian ataupun lingkungan tempat tinggal seharusnya memperhatikan faktor ini dan dapat memberikan solusi untuk mendapatkan kenyamanan termal.

\subsection{Analisis Kategori Faktor Sarana Lingkungan}

Sarana lingkungan merupakan faktor dominan setelah kenyamanan lingkungan. Hal ini dapat menjadi indikasi bahwa responden membutuhkan berbagai hal yang dapat menunjang kelangsungan hidupnya dan dapat membantu dalam aktivitasnya.

Sarana merupakan salah satu elemen permukiman berupa shell (tempat), yang mana manusia melangsungkan kegiatan atau melaksanakan kehidupan. Oleh karena itu dalam perencanaannya perlu mendapat perhatian khusus agar sesuai dengan rencana kegiatan yang berlangsung (M. Sastra \& Marlina, 2006). Di samping itu, salah satu hal yang penting dari pembangunan perumahan adalah masyarakat mudah untuk mengakses berbagai fasilitas seperti layanan pendidikan dan kesehatan, ruang terbuka, sarana perniagaan dan perdagangan yang menyediakan barang dan jasa (Towers, 2005), seperti yang ada pada beberapa komentar responden dibawah ini.

"Kawasan perumahan yang banyak pohon / tanaman hijau dan memiliki fasilitas di perumahan seperti lapangan olahraga atau taman kompleks (Pegawai Swasta)"

"ada masjid di dalam perumahan, ada fasum, kayak lapangan tapi ada tempat jogging, ada tamannya biar rindang (Pelajar/ Mahasiswa)"

"Yang fasilitasnya lengkap, yang ada berandanya (yang luas) dan halaman depan yang cukup untuk duduk duduk dengan tamu. Lalu sirkulasi udaranya bagus dan banyak tanaman dan aman (Pelajar/ Mahasiswa)"

Berdasarkan keseluruhan deskripsi data teks yang diuraikan responden, sarana lingkungan yang dimaksud yaitu pada ketersediaan dan kualitas sarana yang baik. Ketersediaan sarana di perumahan terdiri dari sarana pelayanan umum dan pemerintahan $(6,92 \%)$, sarana kesehatan (7,35\%), sarana pendidikan (seperti, kampus dan sekolah) $(9,09 \%)$, sarana perbelanjaan dan perniagaan $(8,22 \%)$, sarana pertamanan dan RTH $(59,30 \%)$, dan sarana peribadatan $(9,09 \%)$.

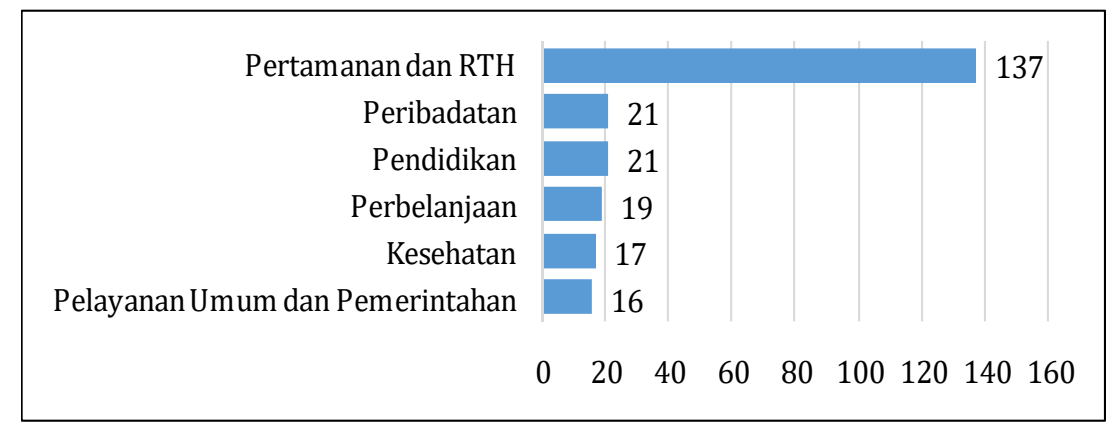

Gambar 3. Analisis Distribusi Frekuensi Kategori Sarana Lingkungan Perumahan

Pada kategori sarana lingkungan kata kunci yang paling sering muncul adalah sarana pertamanan dan RTH (Ruang Terbuka Hijau) yang diuraikan oleh responden sebesar 137 $(59,30 \%)$ dari jumlah data faktor sarana lingkungan. Berdasarkan data teks responden yang 
dimaksud sarana pertamanan dan RTH yaitu dalam bentuk fisik dan suasana seperti tersedianya ruang komunal berupa taman dan terdapat berbagai jenis vegetasi sehingga dapat menciptakan lingkungan yang asri dan alami. Selain itu RTH juga terkait dengan ketersediaan lapangan olahraga yang dapat digunakan sebagai tempat rekreasi serta taman bermain yang dilengkapi dengan rumah baca.

Hal ini menunjukkan bahwa responden menginginkan ruang yang selain dapat berfungsi sebagai tempat sosialisasi antar penghuni juga dapat memberikan kesegaran pada lingkungan perumahan. Lingkungan alami memiliki hubungan positif terhadap aktifitas penghuni pada lingkungan perumahan (Collado et al, 2017). Keberadaan lingkungan alami berupa ruang terbuka hijau, taman dengan elemen softscape dan hardscape yang tertata dan memiliki pemandangan yang menarik memiliki manfaat restoratif (Collado et al, 2017; Kaplan, 1995), dapat membantu individu mengurangi stress (Collado et al, 2017), meningkatkan kesehatan, meningkatkan emosi positif dan menurunkan pikiran negatif (Collado et al, 2017), serta dalam jangka panjang dapat meningkatkan kesejahteraan hidup (Collado et al, 2017; Kaplan, 2001). Sebagaimana pula dijelaskan oleh Direktorat Jenderal Penataan Ruang dalam bukunya Ruang Terbuka Hijau Sebagai Unsur Utama Tata Ruang Kota (2006), RTH berperan besar dalam mencapai pembangunan kota layak huni yaitu kondisi kehidupan yang sehat, nyaman dan berkelanjutan, yang mana salah satu fungsi ruang terbuka hijau yaitu fungsi sosial budaya yang didalamnya dapat menjadi media komunikasi antar warga dan tempat rekreasi secara aktif maupun pasif seperti berolahraga, bermain ataupun kegiatan lainnya.

\subsection{Analisis Kategori Faktor Prasarana Lingkungan}

Prasarana pada lingkungan perumahan disediakan untuk memberikan kemudahan bagi penghuni (Gambar 4). Prasarana merupakan salah satu elemen dasar permukiman yang harus dipenuhi, dapat berupa sistem buatan maupun alami yang berfungsi untuk operasional suatu wilayah permukiman (Doxiadis dalam M. Sastra \& Marlina, 2006), seperti yang ada pada beberapa komentar responden dibawah ini.

“... akses jalan dan jaringan yang baik (Wiraswasta)”

“... sumber air melimpah dan jaringan internet lancar (Pelajar/ Mahasiswa)"

“...tidak banjir (Wiraswasta)”

Kata kunci yang dominan muncul yaitu drainase baik sebesar 32 (28,57\%). Berdasarkan data teks responden, yang dimaksud dengan drainase baik yaitu saluran pembuangan yang lancar dan kondisinya baik. Sehingga dapat menciptakan lingkungan yang aman terhadap luapan air sungai, banjir maupun genangan air. Selain itu drainase yang terhubung dengan daerah resapan air juga membantu untuk mengalirkan dan meresapkan air permukaan ke dalam tanah, sehingga dapat mereduksi banjir dan sebagai penyimpan cadangan air tanah untuk daerah yang mengalami krisis air (Waluyo, n.d). 


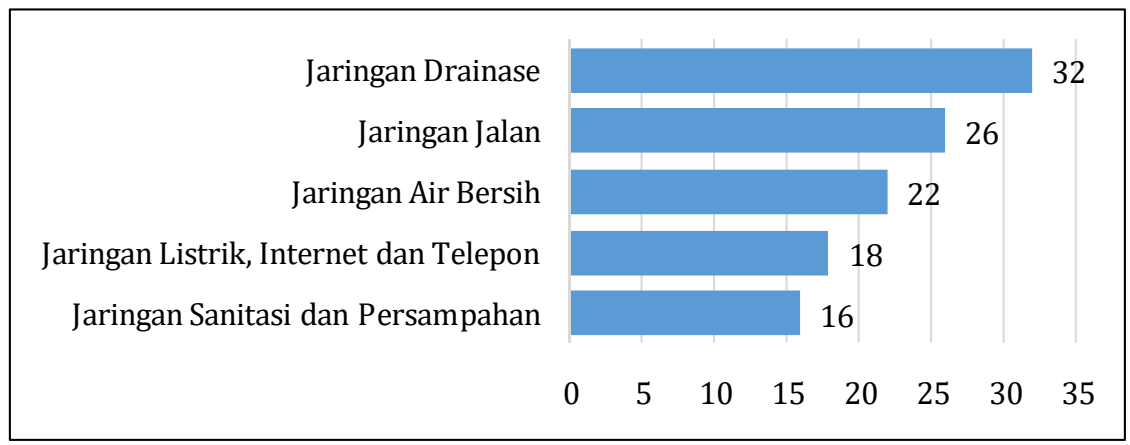

Gambar 4. Analisis Distribusi Frekuensi Kategori Prasarana Lingkungan Perumahan

Faktor lainnya yang mempengaruhi preferensi masyarakat dalam perumahan yaitu ketersediaan jaringan air bersih yang lancar (19,29\%), ketersediaan jaringan listrik, internet dan sinyal telepon yang lancar $(15,7 \%)$. Kondisi jalan yang baik $(22,80 \%)$ pada lingkungan juga menjadi salah satu faktor penting di perumahan yang dilihat dari kondisi fisik jalan yang bagus dan memiliki ukuran jalan yang lebar untuk kelancaran akses di lingkungan perumahan.

Jaringan sanitasi dan persampahan $(\mathbf{1 4 , 0 3 \% )}$ juga menjadi faktor yang dipertimbangkan masyarakat terkait lingkungan perumahan. Sanitasi dan sistem persampahan yang dimaksud responden, yaitu ketersediaan pengolahan limbah yang baik pada perumahan. Sistem tersebut dapat dibuat secara komunal ataupun individu, pengolahan limbah tersebut bukan hanya terkait faktor fisik (seperti septictank komunal, tersedianya tempat sampah untuk pemilahan sampah organik dan non organik dan tempat pengolahan sampah komunal) namun juga terkait dengan manajemen persampahan pada perumahan seperti perilaku masyarakat dan jadwal pengangkutan sampah yang teratur.

\subsection{Analisis Kategori Faktor Lokasi dan Aksesibilitas}

Berdasarkan interpretasi penulis kategori aksesibilitas dan lokasi merupakan dua hal yang saling berhubungan. Aksesibilitas merupakan ukuran kemudahan pencapaian seseorang dari suatu lokasi ke lokasi lainnya dalam sistem jaringan transportasi yang menghubungkannya.

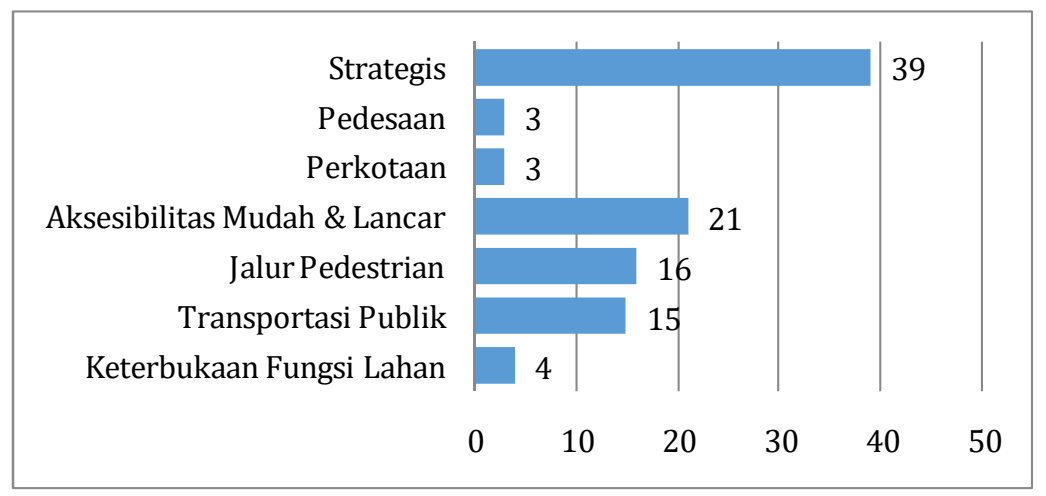

Gambar 5. Analisis Distribusi Frekuensi Kategori Lokasi Dan Aksesibilitas

Berdasarkan hasil analisis data teks yang dimaksud aksesibilitas (20,79\%) oleh responden yaitu kondisi lalu lintas yang lancar dan mudah untuk melakukan mobilisasi 
dari satu tempat ke tempat lainnya dengan ketersediaan transportasi umum $(\mathbf{1 4 , 8 5 \% )}$ dan jalur pedestrian (15,84\%) yang memadai. Pengertian memadai mencakup adanya layak pakai, nyaman, dan terpadu. Jalur pedestrian yang memadai diharapkan dapat mendukung untuk mewujudkan kota yang walkable dan dapat mengurangi polusi udara.

Selain secara fisik aksesibilitas juga terkait kemudahan akses ekonomi seperti dekat dengan tempat kerja, ketersediaan lapangan pekerjaan dan biaya hidup yang terjangkau sehingga kesejahteraan masyarakat dapat meningkat. Seperti pada beberapa komentar responden di bawah ini.

\section{“...Tingkat kesejahteraan masyarakat yang tinggi (Mahasiswa)”}

"Kawasan yg asri, sosial masyarakat nya religius dan tdk individual, dengan biaya hidup terjangkau, kawasannya mudah diakses dan strategis. (Pegawai Swasta)"

Menurut Budiharjo (1994) aspek kedekatan dengan tempat kerja merupakan salah satu preferensi masyarakat dalam pemilihan perumahan. Namun akan berbeda terkait kondisi latar belakang sosial ekonomi seperti tingkat pendidikan, jenis pekerjaan dan tingkat penghasilan.

Selain terkait dengan aksesibilitas, terdapat beberapa lokasi yang menjadi preferensi responden terkait perumahan yaitu lokasi yang strategis $(38,61 \%)$, lokasi di pedesaan $(2,97 \%)$ dan perkotaan $(2,97 \%)$. Lokasi strategis merupakan faktor yang cukup banyak disampaikan responden karena terkait jumlah ketersediaan fasilitas dan kemudahan pencapaian fasilitas dalam rangka pemenuhan kebutuhan hidup.

\subsection{Analisis Kategori Faktor Desain}

Faktor lain yang menjadi preferensi masyarakat dalam memilih perumahan yaitu desain. Pada faktor desain terdapat tiga faktor yang mempengaruhi (Gambar 6) yaitu gaya bangunan dan kawasan sebesar 32 (43,24\%), kualitas lingkungan dan bangunan sebesar $28(37,83 \%)$, dan jenis hunian sebesar 14 (18,91\%).

Pada faktor desain, gaya bangunan dan kawasan merupakan kategori yang banyak dipilih oleh responden yaitu sebesar 32 (43,24\%). Menurut Tambunan (2011) saat ini banyak perumahan ataupun bangunan yang dibangun dengan tema tertentu, seperti pada data responden yang menyebutkan tentang lingkungan perumahan yang bernuansa pedesaan, rumah berkonsep resort, dan rumah tropis.

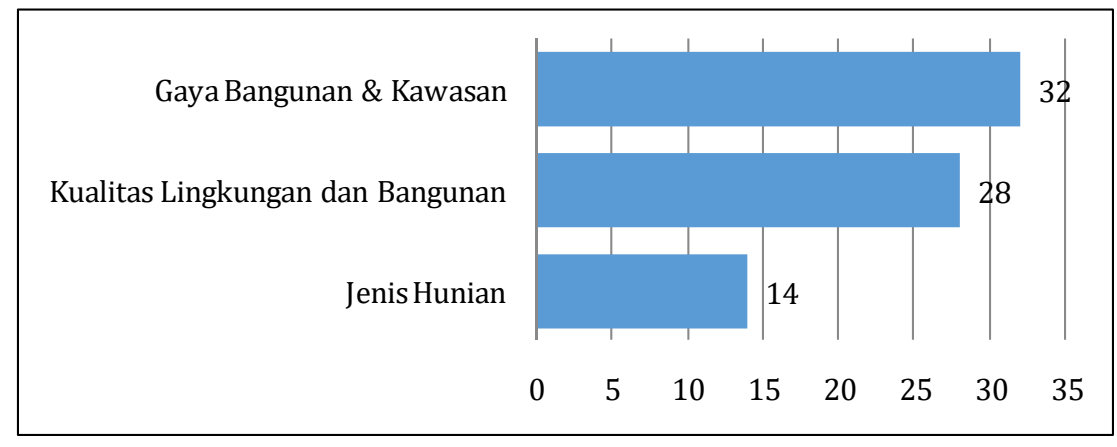

Gambar 6. Analisis Distribusi Frekuensi Kategori Desain

Selain gaya bangunan dan kawasan, responden juga mempertimbangkan faktor kualitas lingkungan dan bangunan dalam preferensi pemilihan lingkungan perumahan 
yang terdiri dari lingkungan yang tertata, perumahan yang tidak padat dan kualitas bangunan yang baik seperti pada penggunaan material dan terdapatnya fasilitas yang ada di dalam rumah. Seperti yang ada pada beberapa komentar responden dibawah ini.

“Tingkat 3, 6 kamar, 2 wc, pdam... (Mahasiswa)"

"Rumah yang nyaman, berukuran sedang, minimal memiliki 3 kamar. Terdapat halaman untuk membuat taman... (Pegawai Swasta)"

\section{“Material baik (Pegawai Swasta)"}

Faktor lainnya yang mempengaruhi faktor desain yaitu jenis hunian yang diinginkan $(18,91 \%)$. Pada faktor ini ada yang memilih jenis hunian mewah, apartemen, paviliun, dan real estate. Adapula responden yang berpendapat bahwa ingin memiliki desain rumah yang sederhana dan layak huni.

Tambunan (2011) mengatakan bahwa salah satu aspek yang dipertimbangkan konsumen dalam memilih perumahan yaitu keindahan dan keunikan desain serta fungsi rumah yang dapat memenuhi kebutuhan dalam beraktivitas dan peluang dalam pengembangan rumah di kemudian hari. Pertimbangan ini juga dipengaruhi oleh perubahan fungsi tempat tinggal dari masa ke masa, yang mana pada awalnya tempat tinggal hanya sebatas tempat berteduh sampai kepada menjadi lambang prestise (Santoso \& Riviwanto, 2011).

Perbedaan pemilihan desain perumahan maupun rumah dapat disebabkan adanya perbedaan kondisi sosial ekonomi, budaya hingga pengalaman terkait lingkungan perumahan. Hal ini diperkuat pada penjelasan Maslow (1994) bahwa tempat tinggal selain sebagai tempat berlindung juga dapat menjadi identitas dari penghuni rumah yang dapat ditemu kenali (affiliation needs), sebagai kebutuhan penghargaan atas diri sendiri (esteem needs) dan tempat tinggal sebagai aktualisasi diri (cognitive and aesthetic needs).

Dari hasil analisis di atas, diperoleh lima faktor dominan yang menjadi preferensi masyarakat pada lingkungan perumahan yaitu kenyamanan lingkungan (F:288) (aspek non fisik), sarana (F:231), prasarana (F:112), lokasi dan aksesibilitas (F:108) dan desain (F:74) (aspek fisik). Apabila melihat sub kategori, maka sub kategori yang memiliki frekuensi yang dominan yaitu pertamanan dan RTH (Ruang Terbuka Hijau) (F:137), ketenangan lingkungan (F:127), hubungan sosial (F:68), kesehatan lingkungan (F:58) dan lokasi strategis (F:39). Lima faktor/kategori dan sub kategori tersebut disusun dalam model hipotesis, seperti yang diperlihatkan pada gambar 7. Dalam model tersebut dimensi lingkaran dari setiap kategori/faktor dan sub-kategori mengikuti frekuensi masing-masing. Dimensi semakin besar menunjukkan bahwa kategori atau sub kategori tersebut semakin dominan.

Selain lima faktor tersebut, terdapat faktor lain yang mempengaruhi preferensi lingkungan perumahan, yaitu faktor biaya dan regulasi (lihat gambar 1). Faktor biaya dan regulasi tidak dimasukkan ke dalam model karena hanya mewakili 0,38\% dari keseluruhan data responden. Berdasarkan data teks responden, faktor biaya dan regulasi terdiri dari keterjangkauan harga dan manajemen perumahan. Faktor biaya yaitu harga rumah (daya beli) yang terkait dengan angsuran rumah yang terjangkau bagi masyarakat tingkat ekonomi menengah maupun ke bawah. Dari hal tersebut faktor ekonomi dapat menjadi faktor penentu dalam memutuskan pilihan hunian.

Faktor regulasi yang dideskripsikan pada data teks yaitu terkait sistem pengelolaan lingkungan dan administrasi yang baik. Pengelolaan lingkungan dan administrasi yang dimaksud adalah mulai dari perencanaan pembangunan hingga pasca pembangunan, seperti 
memperhatikan kualitas dari tiap rumah dan lingkungan perumahan, perizinan bangunan maupun kesesuaian dengan rencana tata guna lahan. Faktor regulasi merupakan faktor normatif yang harus dipenuhi oleh pengembang perumahan maupun oleh pemerintah karena aspek ini terkait dengan peraturan, status hukum dan kebijakan pembangunan perumahan seperti kejelasan peruntukan tanah dan kejelasan kepemilikan tanah (Catanese dan Snyder, 1992).

Jika merujuk pada teori ekistics (Doxiadis, 1970) dan teori perencanaan perumahan (Catanese dan Snyder, 1992), aspek non fisik dan fisik dari kelima faktor preferensi lingkungan perumahan adalah hal yang tidak dapat dipisahkan karena lingkungan perumahan merupakan suatu sistem yang terdiri dari elemen-elemen penyusunnya dan saling terkait satu dengan yang lainnya yaitu manusia sebagai penghuni dan pelaku utama (isi) dan lingkungan huniannya (tempat) (Doxiadis dalam M. Sastra \& Marlina, 2006).

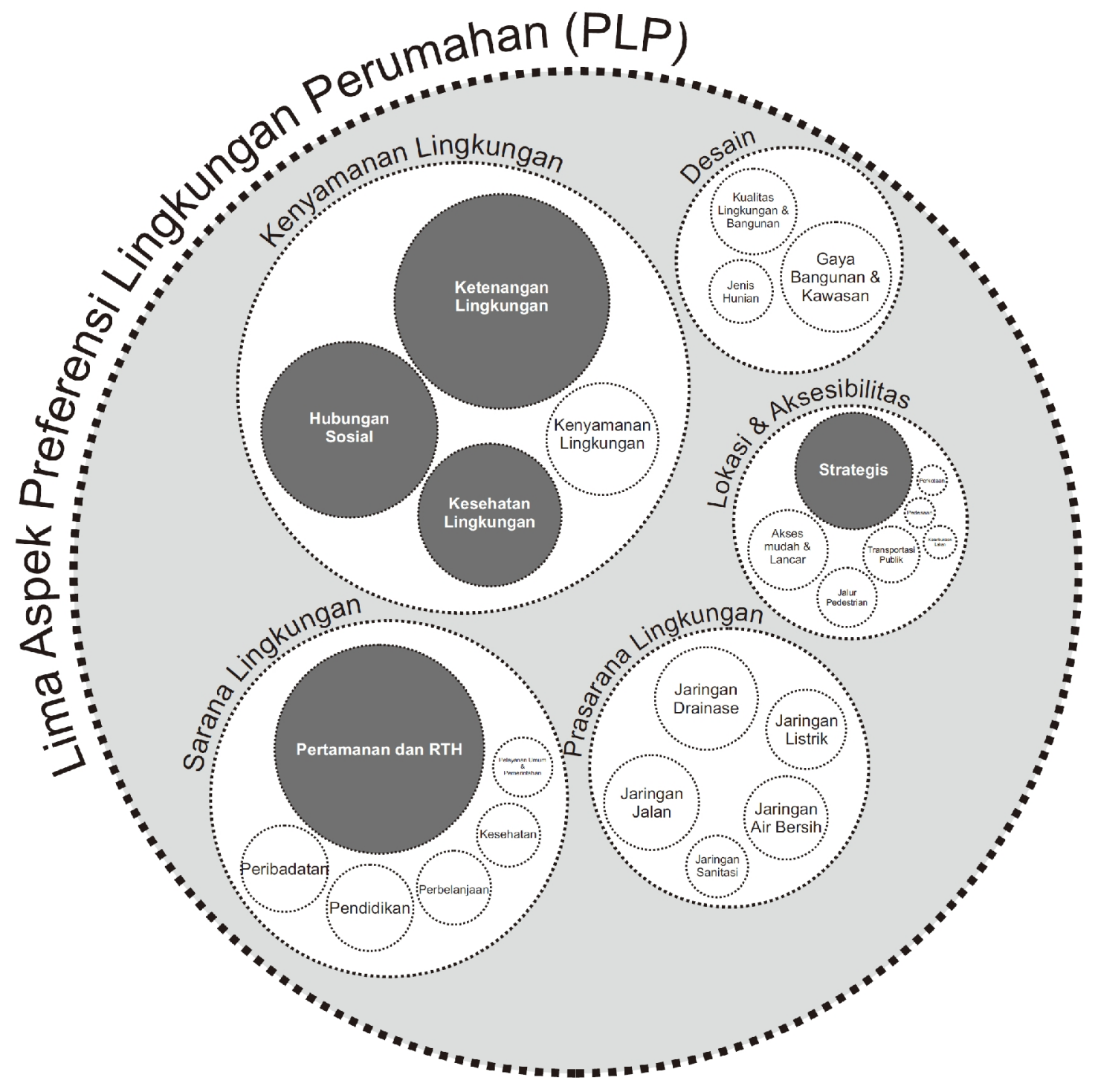

Gambar 7. Model Hipotesis Preferensi Lingkungan Perumahan (PLP) 


\section{Simpulan}

Preferensi masyarakat terkait lingkungan perumahan yang ingin ditinggali terdiri dari dua aspek yaitu aspek non fisik dan aspek fisik. Adapun aspek non fisik yaitu kenyamanan lingkungan, terdiri dari ketenangan lingkungan, hubungan sosial, kesehatan dan kenyamanan lingkungan. Sedangkan aspek fisik terdiri dari sarana, prasarana, lokasi dan aksesibilitas, serta desain. Dalam penelitian juga ditemukan bahwa sub kategori pertamanan dan RTH (Ruang Terbuka Hijau) merupakan aspek preferensi yang paling dominan pada lingkungan perumahan yang ingin ditinggali. Dalam perencanaan lingkungan perumahan hendaknya aspek-aspek tersebut dapat menjadi bahan pertimbangan.

Penelitian ini dilaksanakan dengan pendekatan grounded theory, sehingga temuan penelitian memiliki orisinalitas yang tinggi. Tetapi data penelitian dikumpulkan dengan metode non random sampling yang membuat tingkat generalisasi temuan terbatas. Untuk meningkatkan reliabilitas dan generalisasi diperlukan penelitian replikasi yang menggunakan metode random sampling agar pemilihan sampel lebih representatif, mengingat preferensi seseorang terhadap tempat tinggal akan berbeda sesuai dengan latar belakang pengguna, baik latar belakang sosial budaya, demografi, ekonomi serta tempat bertinggal saat ini. Selain itu diusulkan pula beberapa studi lanjutan, yaitu: alasan pemilihan lingkungan perumahan, pengaruh kualitas lingkungan perumahan terhadap kepuasan penghuni dan pengaruh RTH (Ruang Terbuka Hijau) terhadap kualitas hidup di lingkungan perumahan karena RTH merupakan salah satu aspek yang paling dominan disampaikan oleh responden.

\section{Daftar Pustaka}

Aini, Nurul. 2015. Respon Masyarakat terhadap Konsep Perumahan Berbasis Agama: Perumahan Islami. Prosiding Temu Ilmiah IPLBI, C077-C084.

Anindyajati, Dyah, J., et al. 2014. Preferensi Keluarga Muda Dalam Memilih Rumah Tinggal di Surabaya Berdasarkan Atribut Fisik dan Infrastruktur Perumahan. Prosiding Seminar Nasional Manajemen Teknologi XX ITS, Surabaya, B18-1 s.d B18-8.

Budiasih, I Gusti, A, N. 2014. Metode Grounded Theory Dalam Riset Kualitatif. Jurnal Ilmiah Akuntansi dan Bisnis. 9 (1), 19-27.

Budihardjo, Eko. 1994. Percikan Masalah Arsitektur Perumahan, Perkotaan. Yogyakarta: Gadjah Mada University Press.

Catanese, Anthony, J \& Snyder, James, C. 1992. Perencanaan Kota. Jakarta: Erlangga.

Collado, Silvia., et al. 2017. Restorative Environments and Health. In Bahi, Ghozlane, F., et al (Ed.), Handbook of Environmental Psychology and Quality of Life Research (127-148). Switserland: Springer.

Creswell, John, W. 2007. Qualitative Inquiry and Research Design: Choosing Among Five Approaches. California: Sage Publications, Inc.

Creswell, John, W. 2008. Research Design: Qualitative, Quantitative, and Mixed Methods Approaches. California: Sage Publications, Inc.

Doxiadis, Constantinos, A. 1970. Ekistics, the Science of uman Settlements. Form Science. 170 (3956), 393-404.

Kaplan, Rachel. 2001. The Nature of The View From Home: Psychological Benefits. Environment and Behavior. 33, 507-542.

Kaplan, Stephen. 1995. The Restorative Benefits of Nature: Toward an Integrative Framework. Journal of Environmental Psychology. 15, 169-182.

Kumar, Ranjit. 2005. Research Metodology, A Step by Step Guide for Beginner. London: Sage Publications.

Laurens, Joyce, M. 2005. Arsitektur dan Perilaku Manusia. Jakarta: PT. Grasindo. 
Maslow, Abraham, H. 1994. Motivasi dan Kepribadian 1: Teori Motivasi dengan Pendekatan Hirarki Kebutuhan Manusia. Jakarta: PT. Pustaka Binaman Pressindo.

M, Sastra, S \& Marlina, Endy. 2006. Perencanaan dan Pengembangan Perumahan. Yogyakarta: ANDI Yogyakarta.

Nadiya, Elzsa. 2017. Studi Preferensi Generasi Y Dalam Memilih Hunian di Jakarta Barat. Jurnal Muara Ilmu Ekonomi dan Bisnis. 1 (1), 145-152.

Peraturan Menteri Dalam Negeri Nomor 9 Tahun 2009 Tentang Pedoman Penyerahan Prasarana, Sarana dan Utilitas Perumahan dan Permukiman Di Daerah.

Rahman, Azman, A., et al. 2015. Residents Preference on Conservation of The Malay Traditional Village in Kampong Morten, Malacca. Procedia Social and Behavioral Sciences. 202, 417 423.

Santoso, Eddy, I. 2012. Kenyamanan Termal Indoor Pada Bangunan di Daerah Beriklim Tropis Lembab. Indonesia Green Technology Journal. 1 (1), 13-19.

Santoso, Imam \& Riviwanto, Muchsin. 2011. Konsep dan Pendekatan Rumah. In Kasjono, Heru, S (Ed.), Penyehatan Pemukiman (1-20). Yogyakarta: Gosyen Publishing.

Sueca, Ngakan, P., et al 2001. Faktor-faktor Determinan Pengetahuan dan Persepsi Masyarakat Tentang Bangunan Berlanggam Bali. Dimensi Teknik Arsitektur. 29 (2), 157-164.

Tambunan, Damelina, B. 2009. Atribut yang Menjadi Pertimbangan Konsumen dalam Membeli Produk Perumahan. Jurnal Manajemen Bisnis. 2 (2), 141-153.

Tamboeo, Gunawan., et al. 2016. Dampak Sosial dari Pola Perumahan Permata Asri Pineleng. Jurnal Spasial. 3 (1), 36-45.

Tower, Graham. 2005. An Introduction To Urban Housing Design: At Home In The City. Oxford: Architectural Press of Elsevier.

V. Dokmeci, L., et al. 1996. Residential Preferences in Istanbul. Habitat INTL. 20 (2), 241-251.

Waluyo, A. (n.d.). Sumur resapan yang terintegrasi dengan saluran drainase. Retrieved from http://www.academia.edu/9591388/Sumur Resapan yang Terintegrasi dengan Saluran Drainase

Winanto, Agus., et al. 2016. Analisis Preferensi Atribut Terhadap Keputusan Konsumen Membeli Rumah di Kota Palembang. Jurnal Aplikasi Manajemen (JAM). 14 (1), 46-47.

Zinas, Bako, Z \& Mahmud Bin Mohd Jusan. 2012. Housing Choice and Preference: Theory and Measurement. Procedia Social and Behavioral Sciences. 49, 282-292. 